Aleksandar Zdravković ${ }^{1}$

Mihajlo Đukić ${ }^{2}$

Aleksandra Bradić-Martinović ${ }^{3}$
JEL: F21, 011, C23

DOI:10.5937/industrija45-13548

UDC:339.727.22(4-664)"2000/2014"

331.57

Original Scientific Paper

\title{
Impact of FDI on Unemployment in Transition Countries: Panel Cointegration Approach $^{4}$
}

\author{
Article history: \\ Received: 10 October 2016 \\ Sent for revision: 17 November 2016 \\ Received in revised form: 20 January 2017 \\ Accepted: 20 January 2017 \\ Available online: 5 April 2017
}

\begin{abstract}
This paper examines the relationship between FDI inflow per capita and unemployment rates in 17 transition countries over the period 2000-2014. It aims at testing the premise, usually suggested by policy makers, that higher attraction of FDI in transition countries results in inevitable unemployment reduction. The empirical analysis contributes to the existing literature applying panel cointegration approach in testing and assessing long-run impact of FDI on unemployment, as an alternative to typical panel analysis that examine contemporaneous relations. The evidence from seven performed panel cointegration tests provide the mixed results, while the Fully Modified and Dynamic OLS panel estimations indicate that FDI and unemployment are most likely not cointegrated. The inconclusiveness of the empirical evidences gives the argument in support of the general conclusion that long-run impact of FDI on unemployment in transition countries is either very loose or does not exist.
\end{abstract}

Keywords: FDI, Unemployment, Panel Cointegration Analysis, Transition Countries.

\footnotetext{
${ }^{1}$ Institute of Economic Sciences, Belgrade, e-mail:aleksandar.zdravkovic@ien.bg.ac.rs ${ }^{2}$ Institute of Economic Sciences, Belgrade

${ }^{3}$ Institute of Economic Sciences, Belgrade

${ }^{4}$ The paper presents the results of a study conducted as part of the projects 47009 and 179015 funded by the Ministry of Education, Science and Technological Development of the Republic of Serbia.
} 
Zdravković A. et al.: Impact of FDI on Unemployment in Transition Countries: Panel...

\section{Uticaj stranih direktnih investicija na nezaposlenost u tranzicionim zemljama: kointegraciona analiza panela}

Apstrakt: $U$ ovom radu je analiziran odnos između priliva stranih direktnih investicija per capita $i$ stopa nezaposlenosti u 17 tranzicionih zemalja za period 2000-2014. Cilj rada predstavlja testiranje pretpostavke, često isticane od strane kreatora ekonomskih politika, da privlačenje stranih direktnih investicija neminovno dovodi do smanjenja nezaposlenosti. Doprinos empirijske analize postojećoj literaturi se ogleda u primeni kointegracione analize panela u cilju testiranja $i$ ocenjivanja dugoročnog uticaja SDI na nezaposlenost, umesto standardne analize panela koja ispituje kratkoročne efekte. Rezultati primenjenih panel kointegracionih testova nisu jednoznačni, dok rezultati ocenjivanja potpuno modifikovanom $i$ dinamičkom metodom najmanjih kvadrata sugerišu da SDI i nezaposlenost verovatno nisu kointegrisane. Neusaglašenost empirijskih rezultata ide u prilog opštem zaključku da je dugoročni uticaj SDI na nezaposlenost u tranzicionim zemljama ili veoma slab ili opšte ne postoji.

Ključne reči: strane direktne investicije, nezaposlenost, kointegraciona analiza panela, tranzicione zemlje.

\section{Introduction}

Transition countries in general have structural economic problems such as lack of domestic capital, restructuring of enterprises and integration into the global economy. In the context of the financial crisis and global slowdown of capital flows, these problems were exacerbated by impossibility of achieving economic growth and deterioration of other economic indicators including unemployment. In addition to economic and political reforms, attraction of foreign direct investments (FDI) has been widely considered by policy makers as a very important source of capital used to support economic growth, ensure technology spillover, help restructuring of the economy and reduce unemployment. Impact of the FDI inflow has been a priori taken as granted, even without measuring precise effects on particular macroeconomic indicators. It has been assumed that FDI will, inter alia, have positive impact on the labour market influencing reduction of the unemployment rate. Results of the previously conducted research did not entirely support hypothesis on clear positive impact of FDI on unemployment. Moreover, research results, to the large extent, differ depending on the sample, applied methodology and observed period.

The main objective of this paper is to analyze the long-run impact of FDI inflow on unemployment in selected 17 transition countries over the period 
Zdravković A. et al.: Impact of FDI on Unemployment in Transition Countries: Panel...

2000-2014, using the panel cointegration approach. While existing empirical literature offers the numerous panel studies examining contemporaneous impact of FDI on(un)employment, panel analysis of long-run cointegration hasn't been so frequently explored subject. Given the different FDI inflows recorded in the observed countries, the authors attempted to detect whether these inflows, as argued by the policy makers, have been followed by reduction of the unemployment rates. The authors aimed to enhance general understanding of the impact of FDI on unemployment and transmission channels through which FDI are expected to affect unemployment. This paper did not particularly deal with the specific effects of different types of FDI, targeted industries or financial and other incentives that some transition countries used in order to attract more FDI, which could have indirect effects on the unemployment indicators.

The work is structured as follows. In the second section, it presents results of the previously performed research in the field. Third section provides more details on the applied methodology of panel cointegration testing and estimation. Fourth section presents and discusses findings from empirical anlaysis. Finally, fifth section includes discussion of the results and some of the most indicative concluding remarks.

\section{Literature Review}

Debate on the employment effects of the FDI has been strongly fueled by the empirical results that different authors obtained in the past three decades. Central issues in the FDI-employment relationship debate refer to the questions whether foreign direct investments replace local investment in the host country, are the investments from abroad export oriented, what are the specific sectors targeted by the foreign investors, and whether investments have been oriented to the construction of new plants (greenfield) or acquisition of the existing facilities (Baldwin, 1995; Ernst, 2005). Obtained empirical results are quite divergent. While most of the performed research indicated positive effects of the FDI inflow, especially to the GDP growth, the effects on employment are questionable depending on the observed sector of the economy, form of the attracted FDI, characteristics of the host economy and other factors.

Study performed by Habib and Sarwar over the period 1970-2011, has shown clearly positive effects of FDI on macroeconomic indicators including GDP growth and increase of employment level in Pakistan (Habib \& Sarwar, 2013). Abor and Harvey confirmed that FDI inflow led to higher employment in Ghana within the period 1992-2002, while the effect on wages has been insignificant (Abor \& Harvey, 2008). FDI has been also found to have 
Zdravković A. et al.: Impact of FDI on Unemployment in Transition Countries: Panel...

statistically significant but relatively modest effect on manufacturing employment in Mexico for both working class and more educated workers. Positive effects have been particularly noticed in the export oriented industries (Waldkirch \& Nunnenkamp, 2009). With data set for 23 manufacturing industries observed in the period 1993-2000, Radosevic found evidence to support hypothesis that FDI can reduce erosion of employment. The highest level of impact have been indicated in case of export oriented FDI (Radosevic, Varblane, \& Mickiewicz, 2003). Similar benefits have been confirmed by Pinn and Nguyen (Nguyen, 2013; Pinn, Kok Sook Ching, \& Kogid, 2011). Strat et al. (Strat, Alexandru, Maria, \& Vass, 2015) investigated interdependency between FDI and unemployment. They have shown that, in case of 4 out of 13 latest EU members - Hungary, Malta, Bulgaria and Estonia, there is a causal relationship between FDI and unemployment. However, the opposite relationship has been confirmed in case of Romania, Czech Republic and Slovakia, which means that foreign investors are taking into account locations where there is a lot of available workforce. VAR analysis performed by Balcerzak and Zurek for the period 1995-2009, proved interdependencies between FDI and unemployment. Although FDI inflow has been proved to have favourable impact on labour market through decrease of unemployment rate, positive effects tended to be short-term (Balcerzak \& Żurek, 2011). Unlike Balcerzak and Zurek, in the sample of Western Balkan economies, Kurtovic et al. used panel unit root, cointegration, vector error correction model (VECM) and Granger causality and found long-term positive relationship between FDI inflow and reduction of unemployment for all selected countries with the exception of Serbia and Albania. they argued that the absence of unemployment reduction in these two countries occurred due to the fact that both countries attracted most of FDI in the form of mergers and acquisitions as well as joint ventures (Kurtovic, Siljkovic, \& Milanovic, 2015). Panel unit root, panel cointegration and panel causality tests performed by Mucuk and Demirsel (Mucuk \& Demirsel, 2013) in case of 7 developing countries for the period 1981-2009 have shown divergent results. Although research has confirmed that FDI and unemployment are cointegrated in the long run, there is no evidence to confirm relationship between the two variables in the short run. While FDI inflow influenced higher unemployment in case of Argentina and Turkey, mainly due to negative effects of brownfield investments composed of mergers and acquisitions, unemployment rate has been reduced in Thailand.

In order to evaluate effects of FDI inflow on vacancies creation, Brincikova and Darmo applied adjusted Okun's model on the sample of V4 countries over the period 1993-2012. Results of their research indicate that there is no significant relationship between FDI inflow and employment formulated as employment to population ratio in the observed countries(Brincikova, 2014). Increasing FDI since 2003 did not increase employment rates in the Western 
Zdravković A. et al.: Impact of FDI on Unemployment in Transition Countries: Panel...

Balkan countries. Moreover, they have been generally much lower than the EU average and since 2002 have been stagnating or declining in all countries except Croatia (Estrin \& Uvalic, 2014). Wei revealed that there is no evidence to support positive FDI effects on employment in Chinese economy as a whole. However, there are quite different results when it comes to the effects on particular sector. For example, statistically significant and positive results have been obtained regarding relationship between FDI and employment level in primary sector. On the other hand, there are no evidence on significant relationship between FDI inflows and employment in secondary sector, while the effects on tertiary sector has even been negative (Wei, 2013)

Significant FDI inflow recorded in India during the period 1970-2007 had twofold results in terms of development. Results of the performed multiple regression have shown that abundant FDI inflow has been associated with high growth of GDP which unfortunately, has not been followed by increase in employment level. Relatively modest employment created in both public and private sector proved that despite of relatively large FDI inflows attracted, particularly in the sector of services and to the some extent industrial sector, India recorded so called ,jobless growth"(Mehra, 2013). Obtained results assured authors that economic policy in the future should be more focused on other measures besides FDI to influence unemployment reduction. Similarly, Jenkins has shown that growth of FDI in the 1990s had relatively modest effects to both direct and indirect employment creation in Vietnam. Limited employment generation could be explained by the fact that most of Vietnamese population is employed in the agricultural sector and sector of services where FDI inflow has been relatively low. Recorded investments in these sectors has been characterised by low value added and high productivity which additionally effected in lower employment growth. Indirect effects has also been negligible as negative crowding-out effect mostly surpassed positive effects of creating new market opportunities for local firms (Jenkins, 2006). In order to explain empirically confirmed negative effects of the FDI, Ernst argued that most of FDI did not go into new productive activities but to the service sector, in the form of mergers and acquisitions. Since they have been associated with privatizations and restructuring of banks, FDI used existing assets rather than creating new ones (Ernst, 2005).

\section{Methodology and data}

In this work we applied panel cointegration approach, similar to work of Mucuk and Demirsel (2013) and Kurtovic et al. (2015). It basically consists of two interdependent methodological steps, panel unit root tests and panel cointegration testing. 
Zdravković A. et al.: Impact of FDI on Unemployment in Transition Countries: Panel...

\subsection{Panel unit root tests}

The majority panel unit root tests are developed as an extension of the traditional univariate augmented Dickey-Fuller (ADF) unit root test. The generic case of panel $A D F$ test can be presented by the following equation:

$\Delta y_{i, t}=\rho_{i} y_{i, t-1}+\sum_{p=1}^{P_{i}} \phi_{i p} \Delta y_{i, t-p}+\varepsilon_{i t}, \quad t=1, \ldots, T, i=1, \ldots, N$

where subscripts $i$ and $t$ denote panel individuals and time period, $y_{i, t}$ is an $i$ th individual process and $\varepsilon_{i, t}$ is a disturbance term identically independently normally distributed, $\varepsilon_{t} \sim N\left(0, \sigma^{2}\right)$, also assumed to be independent across the individuals. Optionally, deterministic components like constant term, time trend and time fixed effects can be specified in ADF equation. In regard to the complexity of the underlying assumptions, they can be considered as "first generation" and "second generation" unit root tests (Hossfeld, 2010). The most frequently used tests of the first generation are the Levin-Lin-Chu (2002) test (LLC) and the Im-Pesaran-Shin (2003) test (IPS). The LLC test relies on very restrictive assumption that all individual processes in the panel follow the same unit root process, testing the null $H_{0}: \rho_{i}=\rho=0$, against the alternative $H_{1}: \rho_{i}=\rho<0$. The IPS test is more flexible and close to reality, allowing the possibility of different unit roots across individuals. For the purpose of statistical inference, the IPS t-bar test statistic is constructed:

$\bar{t}_{N T}=N^{-1} \sum_{i=1}^{N} t_{i T}\left(P_{i}, \phi_{i 1}, \ldots, \phi_{i P_{i}}\right)$

wheret $t_{i T}\left(P_{i}, \phi_{i 1}, \ldots, \phi_{i P_{i}}\right)$ denote a group-mean of individual tabulated tstatistic for each $i^{\text {th }}$ individual process, and $P_{i}$ is a lag order of individual ADF tests determined by info criteria (like AIC or SIC).

The second generation unit root tests relax the restrictive assumption on cross-sectional independence. The most notable solution to overcome this issue within ADF panel framework is an extension of the IPS test to so-called Cross-sectionally IPS test (CIPS), proposed by Pesaran (2007). The CIPS test is based on Cross-sectionally ADF regression, wherein lagged crosssectional means of individuals $\bar{y}_{t}$ are included to capture the effects of crosssection common factor as follows:

$\Delta y_{i, t}=\rho_{i} y_{i, t-1}+\varphi_{i} \bar{y}_{t-1}+\psi_{i} \Delta \bar{y}_{t}+\gamma_{l i}{ }^{\prime} D_{l i}+\varepsilon_{i t}, \quad t=1, \ldots, T, i=1, \ldots, N$

The CIPS statistic is then computed in the same manner as described in (2). 
Zdravković A. et al.: Impact of FDI on Unemployment in Transition Countries: Panel...

\subsection{Panel cointegration testing}

The panel cointegration testing is developed in similar fashion as the panel unit root testing, by expanding the univariate case of "Engle-Granger" (EG) approach to cointegration analysis. The EG cointegration test follows the rationale that two non-stationary processes are cointegrated if some linear combination of them is stationary. If cointegrating relation is described in the standard manner by the equation

$y_{i, t}=\beta_{i}{ }^{\prime} x_{i, t}+\varepsilon_{i, t}$

where $y_{i, t}$ and $x_{i, t}$ are vectors of cointegrating variables, then stationarity of linear combination inflicts the assumption on stationarity of $\varepsilon_{i, t}$ residuals, too, that is tested under the null by the EG test. Depending on further specification of regressions for residuals' stationarity testing, EG test can be applied either in parametric (5) or semiparametric (6) way:

$\hat{\varepsilon}_{i, t}=\rho \hat{\varepsilon}_{i, t-1}+\mu_{i, t}$

$\hat{\varepsilon}_{i, t}=\rho \hat{\varepsilon}_{i, t-1}+\sum_{p=1}^{P_{i}} \phi_{i p} \Delta \hat{\varepsilon}_{i, t-p}+\mu_{i, t}^{*}$

Pedroni (2004) proposed seven test statistics for panel cointegration grounded on the EG approach. They can be distinguished to two groups in regard to the initial assumption whether residuals follow the common or different unit root process across individuals. The first group, also known as "within-dimension" or "pooled" tests, includes panel equivalents of variance ratio (denoted as $v$-statistics), Phillip-Peron $\rho$ - and $t$-statistics (parametric and semi-parametric cases) univariate tests. The second group ("betweendimension" or "grouped" tests) includes the same tests as in the first group apart from $v$-statistics computed on the group-mean principle, similar to univariate case of the IPS tests described in (2). The null being tested is $H_{0}: \rho_{i}=1$ against the alternative $H_{1}: \rho_{i}=\rho<1$ in case of the first group of tests, or alternative $H_{1}: \rho_{i}<1$ in case of the second group. Pedroni (2004) also shows that all proposed cointegration test statistics asymptotically converge to standard normal distribution.

Eventually, the assessment of cointegrating relation in case of panel is based on the standard pooled OLS estimator 
$\hat{\beta}_{N T}=\left(\sum_{i=1}^{N} \sum_{t=1}^{T}\left(x_{i, t}-\bar{x}_{i}\right)^{2}\right)^{-1} \sum_{i=1}^{N} \sum_{t=1}^{T}\left(x_{i, t}-\bar{x}_{i}\right)\left(y_{i, t}-\bar{y}_{i}\right)$

modified to more successfully deal with panel data issues and to prevent potential bias in estimations. Two most frequently used solutions are the Fully Modified OLS (FMOLS) proposed by Pedroni $(1996,2000)$ and Dynamic OLS (DOLS), proposed by Kao and Chiang (1997).

This methodology is applied to the weakly balanced panel dataset comprises FDI per capita and unemployment rates for the group op 17 transition countries during the period 2000-2014 ( $N=17, T=15)$. Data on FDI in USD are retrieved from UNCTAD Statistics, while data on population and unemployment rates are retrieved from World Bank World Development Indicators database (in March 2016). We consider use of FDI per capita instead of FDI to GDP as superior solution of FDI measurement, to keep it more robust toward economic cyclicality reflected in GDP dynamic. Data on FDI per capita are transformed to logarithms as usual in such kind of studies. However, rare occasions in which net FDI outflow is recorded creates "holes" in the FDI data for Azerbaijan after logarithmic transformation being one source of the unbalance data structure. The remaining source of FDI unbalanced structure is lack of several observations for Macedonia at the beginning of the period of analysis. The dataset on unemployment rate is balanced.

\section{Empirical Results}

Choice of proper deterministic terms in ADF specification to perform univariate unit root testing depends mostly on characteristics of considered time series (trend, constant). In case of panel structures simple scattering of data does not provide reliable depiction of time series characteristics. We did more rigorous testing whether the FDI and unemployment rates exhibit time trend, by running the regressions where constant and trend are independent variables. Dummy variable crisis is also added, to capture the potential effects of recent global crisis on unemployment and FDI. It is specified in usual manner as bivariate variable taking 0 values before 2009, and 1 in 2009 and afterwards. The results of these simple regressions are presented in Table 1 (FDI per capita in logarithmic terms). In both cases of unemployment rate (ur) and FDI per capita $\left(I f d i \_p c\right)$, regressions are estimated first by pooled OLS, and then by Fixed Effects estimator on the basis of robust errors. Estimated coefficients in pooled and fixed effects regressions are almost identical, but standard errors and t-statistics are quite different. Nevertheless, according to 
Zdravković A. et al.: Impact of FDI on Unemployment in Transition Countries: Panel...

the results, unemployment rates do not exhibit trend while FDI do exhibit in both estimated cases.

Table 1. Presence of time trend in unemployment and FDI

\begin{tabular}{|c|c|c|c|c|}
\hline \multirow{2}{*}{ Variable } & \multicolumn{2}{|c|}{ ur } & \multicolumn{2}{|c|}{ I_fdi_gdp } \\
\hline & pooled & fixed & pooled & fixed \\
\hline const & 326.0835 & 326.0835 & $-511.7249^{\star * *}$ & $-520.4845^{\star \star \star}$ \\
\hline trend & -0.1556357 & -0.1556357 & $0.2574091^{* * *}$ & $0.2617786^{\star * *}$ \\
\hline crisis & 0.1532154 & 0.1532154 & $-0.9346573^{* * *}$ & $-0.9603985^{\star \star *}$ \\
\hline
\end{tabular}

Source: authors' calculations

Second important moment in choice of proper unit root test is the presence of cross-sectional dependency, which was discussed in methodology section. We provide the results of several statistics testing the null that panel data do not exhibit cross-sectional dependency in Table 2, more particularly BreuschPagan LM (1980), Pesaran scaled LM (2004), Pesaran (2004) and Baltagi, Feng, and Kao bias-corrected scaled LM (2012). The results of all four tests reject the null, implying that the CIPS test should provide more reliable conclusions than the LLC and the IPS.

Table 2. Cross-section dependence tests

\begin{tabular}{|l|c|c|}
\hline \multicolumn{1}{|c|}{ Test } & ur & I_fdi_pc \\
\hline Breusch-Pagan LM & $533.0265^{\star \star *}$ & $998.8411^{\star \star *}$ \\
\hline Pesaran scaled LM & $23.04249^{\star \star *}$ & $51.28665^{\star \star \star}$ \\
\hline Bias-corrected scaled LM & $22.43535^{\star \star *}$ & $50.6795^{\star \star *}$ \\
\hline Pesaran CD & $8.242128^{\star * *}$ & $28.51959^{\star \star *}$ \\
\hline
\end{tabular}

Note: Null hypothesis: No cross-section dependence Levels of significance: ${ }^{*} p<0.1,{ }^{\star *} p<0.05,{ }^{* \star *} p<0.01$

After preliminary analysis of data characteristics, we run LLC, IPS and CIPS panel unit root tests. In case of unemployment only constant is specified in ADF regression, while in case of FDI both trend and constant term are considered. Results of the panel unit root tests for both levels and first differences are given in the Table 3. 
Zdravković A. et al.: Impact of FDI on Unemployment in Transition Countries: Panel...

Table 3. Unit root tests

\begin{tabular}{|c|c|c|c|}
\hline \multirow{3}{*}{ level } & \multirow{2}{*}{ Test } & ur & I_fdi_pC \\
\cline { 2 - 4 } & LLC & intercept & intercept and trend \\
\hline & IPS & $-2.37159^{* * *}$ & $-2.02723^{\star *}$ \\
\cline { 2 - 4 } & CIPS & -0.28483 & 1.9403 \\
\hline \multirow{3}{*}{ first difference } & LLC & -1.766 & -2.540 \\
\cline { 2 - 4 } & IPS & $-8.14159^{* * *}$ & $-3.38753^{* * *}$ \\
\cline { 2 - 4 } & CIPS & $-3.972^{* * *}$ & $-3.43594^{* * *}$ \\
\hline
\end{tabular}

Note: Null hypothesis: Panels are non-stationary; FDI data for Azerbaijan and Macedonia are not included in the CIPS as it requires strongly balanced data Levels of significance: ${ }^{*} p<0.1,{ }^{\star *} p<0.05,{ }^{* \star \star} p<0.01$

Results of the IPS and the CIPS panel unit root testing do not reject the null on presence of unit root in unemployment and FDI levels. On the other side, the LLC does reject the null, nevertheless it has been already discussed that it produces the least trustworthy results being grounded on the very restrictive assumptions. In case of first differences, all tests applied confirmed stationarity in unemployment and FDI panels. Taking into account that the IPS and the CIPS test are more reliable in presence of cross-sectional dependency, we can conclude with high level of certainty that both unemployment rates and FDI per capita are I(1) integrated, which makes reasonable to proceed cointegration analysis.

In the next step we applied tests of panel cointegration, more particularly Pedroni's within- and between-dimension tests. The null hypothesis for both groups of tests assumes no cointegrating relation between unemployment rate and FDI per capita. Results are presented in the Table 3.

Table 4.Cointegration tests

\begin{tabular}{|c|c|c|}
\hline Dimension & Test statistics & Value \\
\hline \multirow{4}{*}{ Within-dimension } & Panel v-Statistic & $1.479548^{*}$ \\
\cline { 2 - 3 } & Panel rho-Statistic & $-2.274523^{* *}$ \\
\cline { 2 - 3 } & Panel PP-Statistic & $-3.826234^{* * *}$ \\
\cline { 2 - 3 } Between-dimension & Panel ADF-Statistic & -0.314286 \\
\hline & Group rho-Statistic & 0.273821 \\
\cline { 2 - 3 } & Group PP-Statistic & $-1.980487^{* *}$ \\
\cline { 2 - 3 } & Group ADF-Statistic & 0.283241 \\
\hline
\end{tabular}

Note: Alternative: common AR coefficients for within-, individual AR coefficients for betweendimension.

Levels of significance: ${ }^{*} p<0.1,{ }^{* *} p<0.05,{ }^{* *} p<0.01$ 
Zdravković A. et al.: Impact of FDI on Unemployment in Transition Countries: Panel...

As Hossfeld (2010) points out, Monte Carlo simulations indicate that Pedroni's test statistics can produce different inference decisions with respect to characteristics of the given panel structure and underlying assumptions. This shows to be case in our analysis, as we got mixed results. In case of withindimension group, 3 out of 4 tests suggest rejection of the null. On the other hand, 2 out of 3 between-dimension tests suggest that the null should not be rejected. Altogether 4 out of 7 tests suggest presence of cointegration between unemployment and FDI, but between-dimensions tests based on the less restrictive assumptions predominantly suggest rejection of this hypothesis. Thus, it was not able to make some robust inference on existence of cointegrating relation between unemployment rate and FDI per capita based on Pedroni's approach to panel cointegration analysis.

In the last step we run cointegration regressions to examine whether the estimated coefficients representing long-run relation between unemployment rate and FDI exhibit some statistical significance. Both the FMOLS and DOLS estimations are applied in pooled and grouped versions, and the results are provided in the Table 5.

Table 5. FMOLS and DOLS estimations

\begin{tabular}{|l|c|c|c|c|}
\hline \multirow{2}{*}{ Estimation method } & \multicolumn{2}{|c|}{ FMOLS } & \multicolumn{2}{c|}{ DOLS } \\
\cline { 2 - 5 } & Pooled & Grouped & Pooled & Grouped \\
\hline \multirow{2}{*}{ Long-run } & -0.379512 & $-0.636627^{\star * *}$ & $\begin{array}{c}-0.268855 \\
(0.202359)\end{array}$ & $\begin{array}{c}0.013826 \\
(0.397048)\end{array}$ \\
\hline Coefficient & $(0.239934)$ & $(0.196544)$ & 195 & 195 \\
\hline No. of obs & 231 & 231 & 0.973117 & \\
\hline R-Squared Adj. & 0.913678 & & & \\
\hline
\end{tabular}

Note: Standard errors in parentheses. The fewer number of observations in DOLS estimates results from dynamic specification of the DOLS regression

Levels of significance: * $p<0.1,{ }^{* *} p<0.05,{ }^{* *} p<0.01$

The estimated long-run cointegrating coefficients are mainly negative in support of the branch of theoretical and empirical literature stating that an increase in FDI has positive impact on employment and stimulate fall in unemployment rates. However, regression coefficients turn to be insignificant in 3 out of 4 versions of panel cointegrating estimates, indicating no long-run relation between unemployment rates and FDI per capita in transitional countries. Again, we cannot make fully robust inference on presence of cointegration, but empirical evidence based on the FMOLS and DOLS estimations from the Table 5 suggest that FDI and unemployment are most likely not cointegrated. 
Zdravković A. et al.: Impact of FDI on Unemployment in Transition Countries: Panel...

Our work is directly comparable, both in methodological and country-wise sense, to studies of Mucuk and Demirsel (2013) for seven developing and even more to Kurtovic et al. (2015) for seven Western Balkan countries. The evidences on cointegration from our study corresponds to the lack of robust conclusions based on the panel analysis that is also found in their works. For instance, Pedroni's tests in Kurtovic et al. (2015) also rejected null hypothesis of no cointegration in 4 out of 7 cases. Beside panel, both of these studies also deal with country-by-country cointegration analysis and again provide mixed evidences, suggesting that difference in intertwining of FDI and unemployment most likely depends on the greenfield and brownfield structure of FDI.

Nevertheless, in comparison to Kurtovic et al. (2015) work, which covers similar time period and several countries also comprised by our sample, we provide more rigorous panel cointegration analysis in several ways. First, our work covers a larger sample of countries and benefits from the considerably higher number of observations. Second, their work does not provide unit root tests on series levels (only in first differences), neglecting the fact that proven first-order integration of both variables in levels is a presumption to proceed cointegration analysis. Finally, we provide variety of estimated cointegrating relations using estimators more suitable for panel framework, with intuitive interpretation of estimated long-run coefficient in terms of semi-elasticity. Yet we didn't go beyond the panel analysis to examine country-by-country cointegrations.

\section{Conclusion}

The positive impact of the FDI inflow on unemployment has been frequently taken as granted by the policy makers in transition countries, even without measuring precise effects and transmission mechanism in which FDI can boost the creation of new employment. Results of the existing empirical studies did not entirely support hypothesis on clear positive impact of FDI on unemployment. Moreover, research results, to the large extent, differ depending on the sample, applied methodology and observed period.

In this work we analyze the long-run impact of FDI per capita on unemployment rate in 17 transition countries, based on panel cointegration approach. The panel cointegration testing provides mixed results and did not produce some robust inference on existence of cointegrating relation between unemployment rate and FDI per capita, based on Pedroni's (2004) approach. The estimated long-run cointegrating coefficients by the FMOLS and the DOLS estimators are mainly negative in support to the premise that an increase in FDI reduces unemployment rates, but without straightforward 
Zdravković A. et al.: Impact of FDI on Unemployment in Transition Countries: Panel...

confirmation of their statistical significance. The inconclusiveness of the empirical evidences gives the argument in support of the general conclusion that long-run impact of FDI on unemployment in transition countries is either very loose or does not exist. The evidences from our work corresponds to the lack of robust conclusions based on the panel analysis that is also found in similar studies, in line with the argument that the impact of FDI on unemployment most likely depends on its greenfield and brownfield structure.

\section{References}

Abor, J., \& Harvey, S.K. (2008). Macroeconomics and Finance in Emerging Market Economies Foreign direct investment and employment: Host country experience. Macroeconomics and Finance in Emerging Market Economies, 1(2), 213-225. doi:10.1080/17520840802323224

Balcerzak, A.P., \& Żurek, M. (2011). Foreign Direct Investment and Unemployment: VAR Analysis for Poland in the Years 1995-2009. European Research Studies, 14(1),

Baldwin, R. (1995). The Effect of Trade and Foreign Direct Investments on Employment and Relative Wages. NBER Working Paper Series, 5037,

Baltagi, B.H., Feng, Q., \& Kao, C. (2012). A Lagrange Multiplier test for Crosssectional Dependence in a Fixed Effects Panel Data Model. Journal of the Econometrics, 170, 164-177.

Breusch, T., \& Pagan, A. (1980). The Lagrange Multiplier Test and its Application to Model Specification in Econometrics. Review of Economic Studies, 47, 239-253.

Brincikova, Z. (2014). The impact of FDI inflow on employment in V4 countries. European Scientific Journal, 1(1), 245-252.

Ernst, C. (2005). The FDI: Employment link in a globalizing world: The case of Argentina. Brazil: and Mexico. Employment Strategy Papers.

Estrin, S., \& Uvalic, M. (2014). FDI into transition economies. Are the Balkans different?. Economics of Transition, 22, 281-312. September 2012. doi:10.1111/ecot.12040

Habib, M.D., \& Sarwar, S. (2013). Impact of Foreign Direct Investment on Employment Level In Pakistan: A Time Series Analysis. Journal of Law, Policy and Globalization, 10, 46-56.

Hossfeld, O. (2010). Equilibrium Real Effective Exchange Rates and Real Exchange Rate Misalignments: Time Series vs. Panel Estimates. Leipzig Graduate School of Management Working Paper, 2010(3),

Im, K., Pesaran, M., \& Shin, Y. (2003). Testing for Unit Roots in Heterogeneous Panels. Journal of Econometrics, 115, 53-74.

Jenkins, R. (2006). Globalization, FDI and employment in Viet Nam. Transnational Corporations, 115-142. Vol. 15.

Kao, C., \& Chiang, M. (1997). On the Estimation and Inference of a Cointegrated Regression in Panel Data. Advances in Econometrics, 15, 179-222.

Kurtovic, S., Siljkovic, B., \& Milanovic, M. (2015). Long-term impact of foreign direct investment on reduction of unemployment: Panel data analysis of the Western 
Zdravković A. et al.: Impact of FDI on Unemployment in Transition Countries: Panel...

Balkans countries. Journal of Applied Economics and Business Research, 5(2), 112-129.

Levin, A., Lin, C., \& Chu, C. (2002). Unit Root Tests in Panel Data: Asymptotic and Finite-sample Properties. Journal of Econometrics, 108, 1-24.

Mehra, N. (2013). Impact of foreign direct investment on employment and gross domestic product in India. Int. J. Eco. Res, 4, 29-38. August.

Mucuk, M., \& Demirsel, T. (2013). The Effect of Foreign Direct Investments on Unemployment: Evidence from Panel Data for Seven Developing Countries. Journal of Business, Economics \& Finance, 2(3), 53-66.

Nguyen, T.M. (2013). Impacts of FDI on technology upgrade and employment of Singapore and Malaysia, lesson for Vietnam.

Pedroni, P. (1996). Fully Modified OLS for Heterogeneous Cointegrated Panels and the Case of Purchasing Power Parity. Indiana University Department of Economics Working paper, 96-020,

Pedroni, P. (2000). Fully Modified OLS for Heterogeneous Cointegrated Panels, Nonstationary Panels. Panel Cointegration and Dynamic Panels, 15, 93-130.

Pedroni, P. (2004). Panel Cointegration: Asymptotic and Finite Sample Properties of Pooled Time Series Tests with an Application to the PPP Hypothesis. Econometric Theory, 20, 597-625.

Pesaran, M.H. (2004). General Diagnostic Tests for Cross Section Dependence in Panels. University of Cambridge Working Papers in Economics, 0435,

Pesaran, M.H. (2007). A simple panel unit root test in the presence of crosssection dependence. Journal of Applied Econometrics, 22, 265-312.

Pinn, S.L.S., Sook, C.K., \& Kogid, M. (2011). Empirical Analysis of Employment and Foreign Direct Investment in Malaysia: An ARDL Bounds Testing Approach to Cointegration. Advances in Management \& Applied Economics, 1(3), 77-91.

Radosevic, S., Varblane, U., \& Mickiewicz, T. (2003). Foreign direct investment and its effect on employment in Central Europe. Transnational Corporations, 12(1), 5390.

Strat, V.A., Alexandru, A.D., Maria, A., \& Vass, P. (2015). FDI and The Unemployment: A Causality Analysis for The Latest EU Members. Procedia Economics and Finance, 23, 635-643. October 2014. doi:10.1016/S22125671(15)00448-7

Waldkirch, A., \& Nunnenkamp, P. (2009). The Journal of Development Employment Effects of FDI in Mexico 's Non-Maquiladora Manufacturing. The Journal of Development Studies, 45(7), 1165-1183. doi:10.1080/00220380902952340

Wei, Y. (2013). The effect of FDI on employment in China. lowa State University. Graduate Theses and Dissertations. Paper 13379. Retrieved from http://lib.dr.iastate.edu/cgi/viewcontent.cgi?article=4386\&context=etd 